地すべり 第17巻 第 4 号

Journal of the Japan Society of Landslide 17-4 (1981)

\title{
新潟県の地すべりと地質および地質構造の関係（2） Relation of Landslide to Geology in Niigata Prefecture
}

\section{福 本 安 正*}

Yasumasa Fukumoto

\section{7. 地すべと地層別地質構造の関係}

地すべりと地質構造の関係の検討は, 背斜構造, 向斜 構造, 断層および迸入岩体の 4 つの因子について検討し た。

背斜構造および向斜構造に属する地すべり地区とは, 地すべり地区内またはその近くを背斜軸あるいは向斜軸 が通っている場合, 前者は地層が撓曲し, 引張応力をう け，また後者は地艘が凹形に湾曲し，王縮応力をらけて いるとして，それぞれこれらの応力が地すべりに影響を 与えているものと想定した。

迸入岩体拉よび断層は, 地すべり地内执よびその周辺 に迸入岩体あるいは断層が存在する場合, これらにより 地層が破砕または脆弱化し, 風化が促進される条件下に あり，その上，迸入岩体の場合は，この岩体に賦存され た地下水の影響も想定して分類した。これらの分類要素 が地すべり発生の素因としていかなる関連を有するかに ついて各地幡毎に検討した。

また，地層の走向掞よび傾斜と地すべりの関係につい ても検討した。具体的には流れ盤地すべり, 受け盤地す ベり，走向地すべりの 3 つに分けて考察した。
流れ盤地すべりとは, 地すべり方向と地層傾斜方向が ほぼ一致する場合で，この逆の場合を受盤地すべりとし た。また, 地すべり力向が走向方向に近いものを走向方 向地すべりとして分類し, 各地層毎にまとめて検討を加 えて，以下のごとき結果がえられた。

なお，新第三紀層の各地域別面積と，その地層におけ る地すべり筒所数, 面積は表-1のと接りである。

（1）魚沼層

魚沼層の地すべりと地質構造の関係を図で示すと眓-1 (1)のごとくである。すなわち, 魚沼層の地すべり地の面 積中に占める背斜構造地すべり面積は $17.8 \%$, 向斜構造 地すべり面積 $4.5 \%$ ，断層地すべり面積1.3\%，その他が 76.9\%である。そして箇所数の各比率も面積比とほぼ同 じ値となっている。すなわち, 魚沼層地すべりは地質構 造的影響は背斜構造のほかはすくないとみることができ る。このことは, 図-2(2)の魚沼層の地域別面積比と地す ベり面積比にもあらわれている。すなわち, この図によ ると, 最も褶曲度の高いIII地域の地すべり面積比が 9 \%, 断㬝が発達し, 迸入岩体の多いII 地域では $0 \%$ とな って扣り，それとは反対に，最も褶曲度の低い $N$ の(2)地 域の地すべり面積比が7.3\%，それよりもやや褶曲度の
(1)

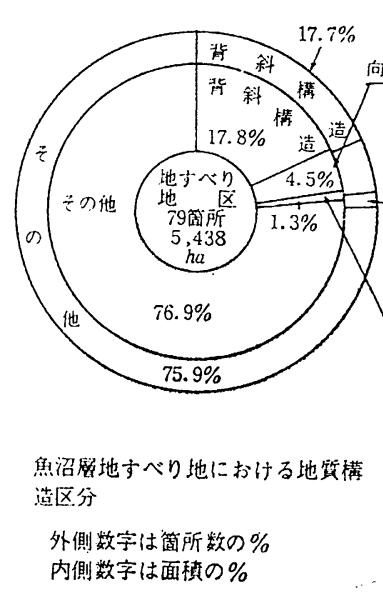

(2)

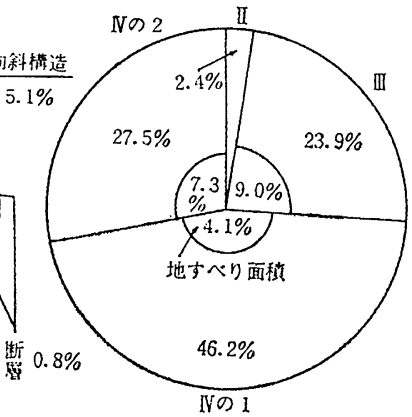

魚沼原の地域別面䅡比（外側の数 宇) とその地骷にお就る地すべり 面榬比（内側の数字）
(3)

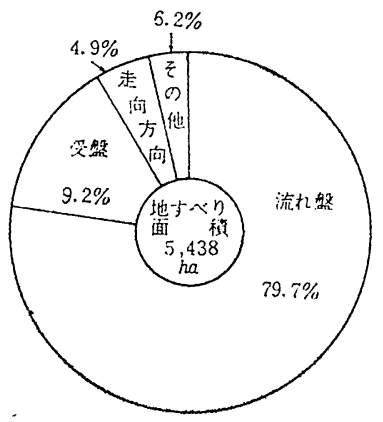

魚沼層の地すべり方向之地售の走 向，傾斜の関倸

図-1

* 新潟県林策試験場 
新潟県の地すべりと地質および地質構造の関係(2)

表-1 新第三紀層の各地域別面積および地すべり箇所数・面積

1978年 1 月現在

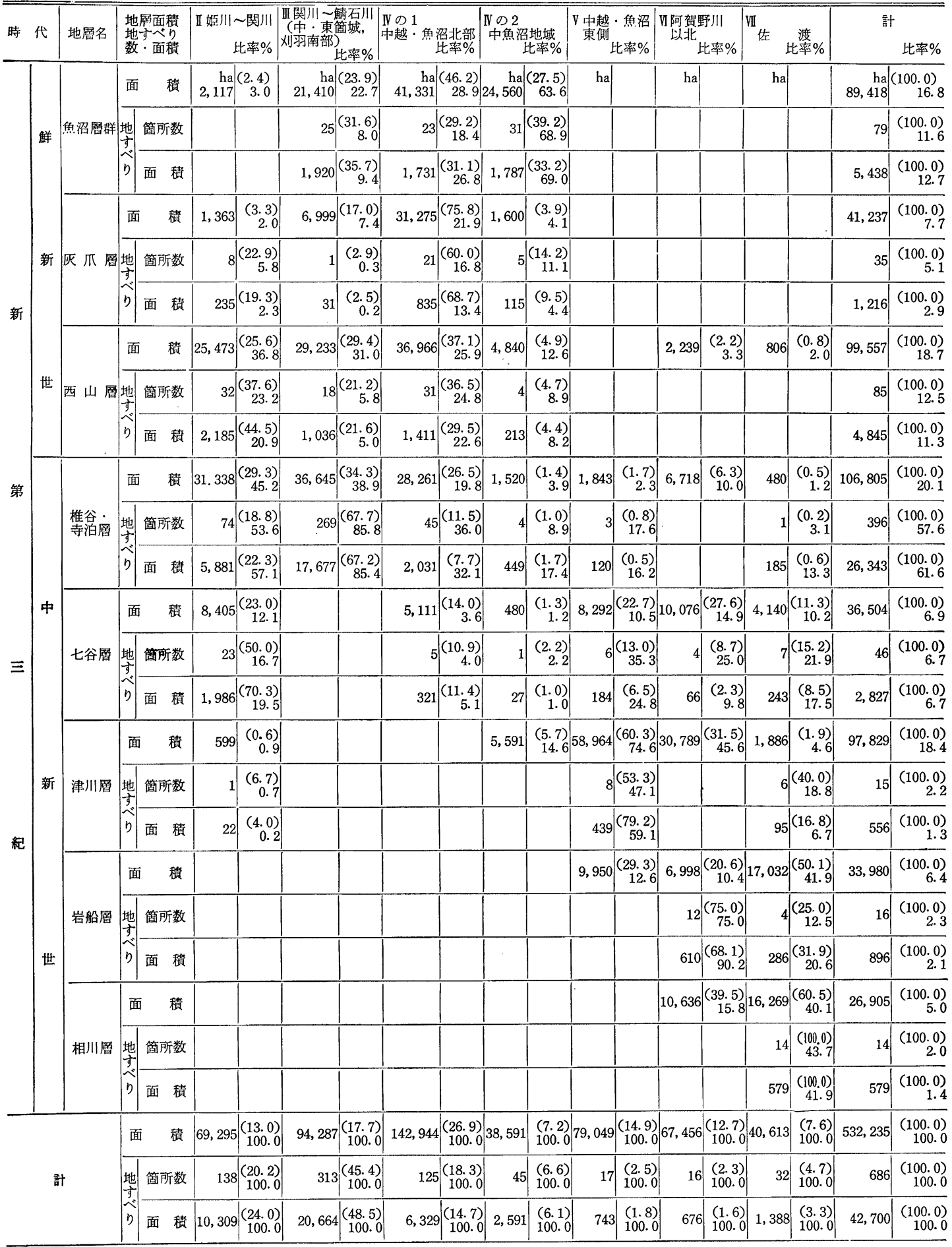

高いNの(2)地域が4. 1\%となって高い比率を示している。 したがって魚沼層の地すべりの発生に関しては地質構造 による影響がむしろ小さいと見ることがでさる。

また，地層の走向，傾斜の関係では，図-1(3)が示す
ごとく，流れ盤地すべりが79.7\%，受盤地すべりが 9.2 \%, 走向地すべりが $4.9 \% て ゙ ，$ 流れ盤地すべりが圧倒的 に多くなっている。このことは第四紀層地すべりの特徴 をよく表現している。すなわち，魚沼層の地層は砂， 
(1)

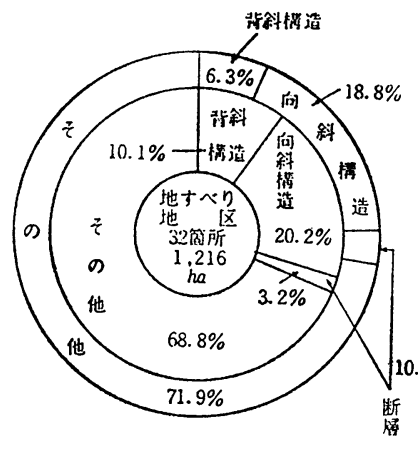

反爪莌地すべり地における地倎構 造区分

外側数字は筒所数の\% 内側数字は面䅡の\%
(2)

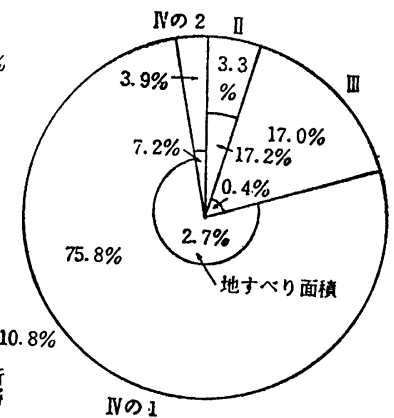

灰爪層の地域別面䅴比 . (外側の数 字) とその地層における地すべり 面稹比（内側の数字）
(3)

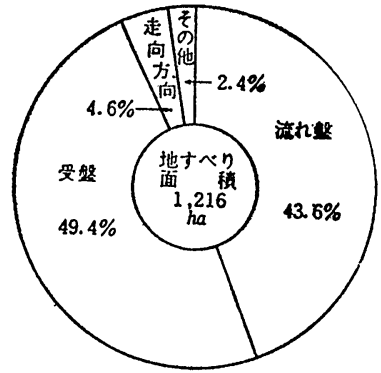

灰爪層の地すべり方向と地显の走 向，傾斜の咸倸

図-2

磁，粘土の互層で，ところどころに頁岩が介在する。し たがって, 砂, 磁の層では透水性がよく, 融雪期や長雨 期には地下水により間隙水圧が上界し, 斜面を不安定に する。とくに頁岩や粘土等の不透水層が地形の傾斜方向 （流れ盤構造）となっていて，その上に透水性の砂，

磷, シルトを互層する場合は地すべり発生に好条件であ る。第四紀層地すべりの発生機構はこのような場合が実 飞多い。

\section{(2) 灰爪層}

兏爪層の地すべりと地質構造の関係は図-2(1)に示すご とく, 面積比にして背斜構造 $10.1 \%$, 向斜構造 $20.2 \%$, 断層 $3.2 \%$ ，その他 $66.5 \%$ となり，背斜扰よび向斜構造 に属するものはすくない。このことは同図(2)と対比して
解明すると一層明らかとなる。すなわち, 櫂曲構造の最 も発達している地域の地すべり面積比はわずか $0.4 \%$ であるのに比し, 褶曲構造の発達のすくない $N$ の(2)では

\section{$7.2 \%$ である。}

地層の走向, 傾斜の関係では, 受盤地すべり 49.4\%, 流れ盤地すべり $43.6 \%$, 走向地すべり $4.6 \%$ であって, 流れ盤, 受盤両地すべりの差がすくなくなっている。す なわち, この地層が主として塊状のシルト岩からなり, 前述の魚沼層よりもはるが透水性が低く，したがって 魚沼層地すべりと発生機構を異にして抢り，地質構造と の関連はむしろすくないとみることができる。

また，地すべりと地層の走向，傾斜の関係では図-2(3) に示すごとく流れ盤と受盤構造の差はすくなく，魚沼層

(1)

(3)
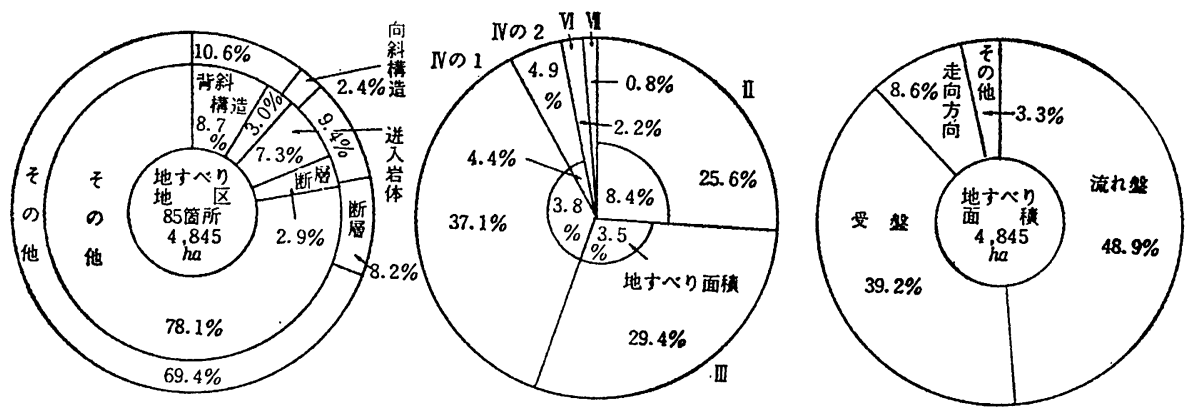

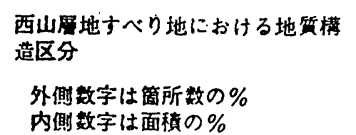

西山層の地域別面稙比（外側の 字)とその地におけ地すべり 面積比 (内側の数字)
西山層の地すべり方向と地屏の走 向, 煩斜の関係 
の土質の相異を反映している。

\section{(3) 西山層}

西山層の地すべりと地質構造の関係は，図-3(1)に示す ごとく, 面積比にして背斜構造 $8.7 \%$, 向斜構造 $3.0 \%$, 迸入岩体 $7.3 \%$ ，断層 2.9\%扣よびその他が78.1\%であ る。前述の灰爪層よりさらに地質構造との関係がすくな いが，迸入岩体の影響が若干大きいことが注目される。 これらのことは同図(2)の地域別面積比と地すべり面積比 にもあらわれている。すなわち，迸入岩体の多いII 地域 の地すべり面積比が若干高く $8.4 \%$ を占め， それに反 し, 迸入岩体のすくないIII, IV の(1)拉よび $\mathbb{N}$ の (2) 地域 は，それぞれ 3.5\%，3.8\%，4.4\%と近似した低い值を 示す。

地層の走向，傾斜の関係では流れ盤地すべり $48.9 \%$, 受盤地すべり $39.2 \%$ ，走向方向地すべり $8.6 \%$ となって いる。前述の灰爪層地すべりでは流れ盤地ず゙りょりも 受盤地すべりが若干多かったが，西山層では逆に流れ盤 地すべりが多く, 次に述べる椎谷, 寺泊層地すべりでは さらにこの差が大きくなるが，西山層はその中間の值を 示す。

\section{（4）椎谷·寺泊層}

椎谷・寺泊層の地すべりと地質構造の関係は, 図-4(1) に示すごとくである。すなわち面積比にして背斜 構造 $37.2 \%$, 向斜構造 $2.9 \%$, 迸入岩体 $7.1 \%$, 断層 $15.1 \%$,

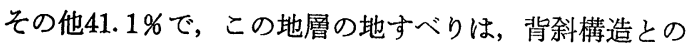
関連が強いことを示している。第三紀層でも他の地層の 地すべりは背斜構造の影響は顕著ではないが, 椎谷・寺 泊層が特に著しいのは椎谷 · 寺泊層が背斜軸の周辺を占 めて分布し，他の地層に比べて過䙮曲度が高いこと，乙 かも地形的にも稜線近くを占めて，傾科が強い部分に分 布することがその原因となっていると考えられる。この
ことは同図(2)に特いてさらに具体的に解明することがで きる。

一方，向斜構造内の地すべりは，魚沼層，灰爪層およ び西山層よりも比率が低い。そして地層が古くなるにつ れて低率となる傾向をあらわしている。このことは，地 層が古くなるにしたがって隆起量が大きく，背斜による 凸状を形成し，向斜部分は地表から相対的に没すること によるものである。

椎谷・寺泊層の地域別面積比と地すべり面積比は同図 (2)に示すごとくである。III 地域では椎谷・寺泊層の占め る面積も大きいが，それと共に地すべり面積比は $47.9 \%$ と王倒的に大きくなっている。この地域は前述のように 褶曲度が高いことと，椎谷・寺泊層より古い地層がきわ めてすくなく，そのため背斜軸は山稜となり，その部分 を椎谷・寺泊層で占有しているからである。褶曲による 地層の撓曲, 破砕による風化の促進と亀裂への地下水の 浸透がこの地域に地すべりを多発させるものと考えられ る。

また，II 地域の地すべり面積比が18.5\% と高くなって いるが，これはこの地域の断層および迸入岩体の影響に よるもので, 兏爪層, 西山層, 椎谷 - 寺泊層と時代が古 くなるにしたがって地層の強度も高くなっているにるか かわらず，椎谷・寺泊地すべり面積が II 地域の地すべり 面積の $57.1 \%$ 占め，きわめて高い率を示す。このよう に, 褶曲構造, 断層执よび貫入岩などが発達している地 域に地すべりが集中していることは，地すべりの発生に 地質構造が有力な素因となっていることを示して扣り， しかも地層が古く, 強度が高くなるにつれ地質構造の影 響が顕著になる。

このことは椎谷 ·寺泊層の地すべり方向と地層の走 向，傾斜の関係をあらわした同図(3)からも考察すること
(2)

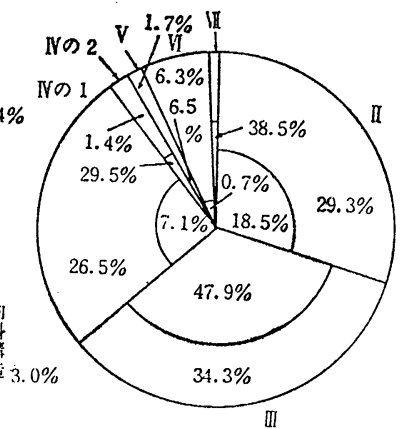

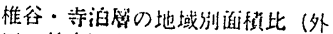
側の数字)と方の地等における地 ナべり面程比(队側の数宇)
(3)

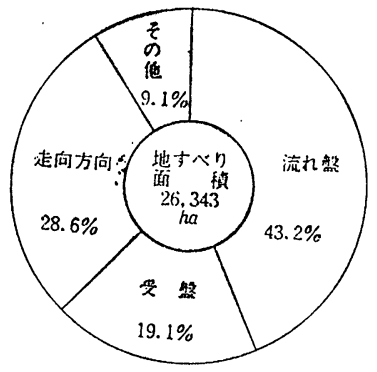

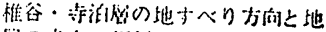

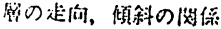


地すべり Vol.17 No.4（1981）

ができる。すなわち，灰爪層，西山層においては流れ盤 地すべりと受盤地すべりはほぼ近似しており，この両方 で大半を占め, 走向方向地すべりは各々 $4.6 \%$ および 8.6 \%とむしろ小さな值を示す。しかしながら，椎谷・寺泊 層に执いては流れ盤地すべり $43.2 \%$, 受盤地すべり 19.1 \%, 走向方向地すべりが28.6\%であって, 走向地すべり が受盤地すべりよりも多くなっている。このことは椎谷 ・寺泊層が背斜部に位㯰していることと共に, 背斜軸に 直交して河川括よび渓流の開析がすすみ，走向方向の斜 面を多くつくっていることによるものである。背斜構造 の極度に発達しているIII地域, それについで発達してい るII およびNの(1)地域においてこのよらな開析地形が多 い。これらの事実から椎谷・寺泊層地すべりは, 地層の 走向, 傾斜には影響されず, 褶曲により地層が破断, 撓 曲することにより，地すべりを発生すると見ることがで き。そして，第三紀層のなかでも地層が古くなり，よ り堅硬な地曆から構成されるにつれてこの傾向が強くな り，次に述べる七谷層も同様な結果を示す。

\section{（5）七谷層}

七谷層地すべりと地質構造の関係は図-5(1)となる。背 斜構造の割合は面積比にして魚沼層 $17.8 \%$, 灰爪層 10.1 $\%$, 西山㬝 $8.7 \%$, 椎谷·寺泊層 $37.2 \%$ となっているの に刘し, 七谷層ではぜ口に等しく, 一方, 迸入岩体に関 する地すべりが $27.8 \%$ ，断層地すべりが $24.3 \%$ といずれ も多くなっている。

この傾向は津川, 岩船凮执よび相川層にも見られ, 地 層が古くなるにつれて, 岩質が緻密で堅硬となり, 地層 傾斜や褶曲よりも迸入岩体や断層による影響が地すべり 発生に支配的になることを示している。

このことはまた, 同図(2)の七谷層の地域別面積比と地 すべり面積比にもあらわれている。すなわち，七谷層が
分布している地域のなかで, 最も断層が発達し, 貫入岩 が多いII 地域で23.6\%とたかい地すべり発生率を示して いる。

地すべり方向と地層の走向, 傾斜の関係は同図(3)のご とくである。この図に抒いても前述の関係がよくあらわ れている。七谷層の岩質はそれより新しい地曆のものよ り堅硬で，そのため地すべりは傾斜，走向，背斜拉よび 向斜に関連して発生することはすくなく, むしろ破研, 龟裂をもたらした断層拉よび迸入岩体に支配されて発生 することを示している。

\section{(6) 津川層}

津川層地すべりと地質構造の関係は，図-6(1)に示すと 招りである。迸入岩体の地すべりが $38.7 \%$, 断層地す

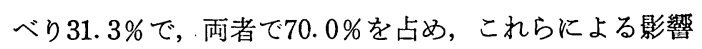
が七谷層よりさらに大きくなっている。

また, 地域別面積比と地すべり面積比の関係は, 同図 (2)に示すごとく, 迸入岩体が最も多い收地域扣よび断層 や貫入体の存在が顕著な II 地域がそれぞれ $4.9 \% ， 3.7 \%$ で, 最も津川層が多く分布しているV地域の地すべり発 生率 $0.7 \%$ よりも高い。

地すべり方向と地層の走向, 傾斜の関係は同図(3)のご とくである。すなわち, 流れ盤地すべり $43.3 \%$, 受盤地 すべり $18.2 \%$, 走向地すべり $8.2 \%$ でって,一見, 地 層傾斜に影響されているように見学るが，津川層の流れ 盤に属する地すべりは貫入岩体によって誘発されたもの が大部分であって, 魚沼層, 灰爪層, 西山層および椎谷, 寺泊層の流れ盤地すべりの大半が褶曲によるものとは内 容が相違している。

\section{（7）岩船層}

岩船層に括ける地すべりと地質構造の関係は, 図-7(1) に示すと拉りである。迸入岩体と関係すると思われる地
(1)

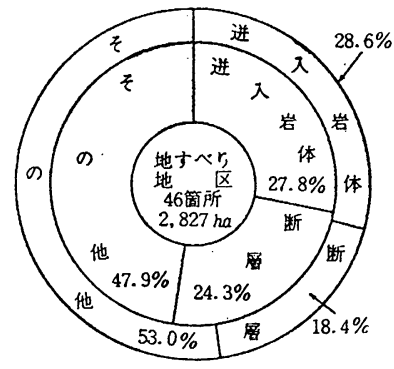

七谷層地すべり地における地質棈 造区分

外僋の数字は筒所数の\% 内側の数字は面稓の\%
(2)

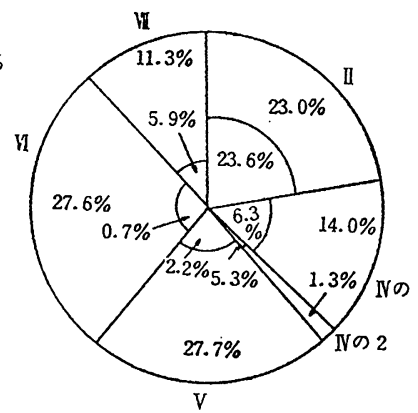

七谷層の地域別面䅪比（外側の数 字) とその地首におけろ地すべり 面潄比（内㒋の数字）
(3)

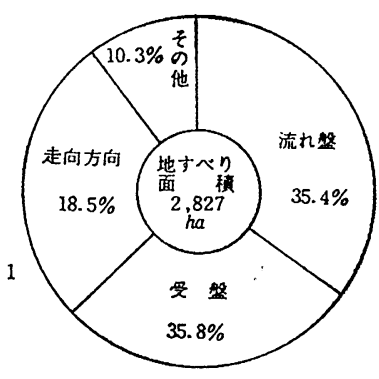

七谷缯の地すべり方向と地居の走 向, 頃斜の湖傒 
(1)

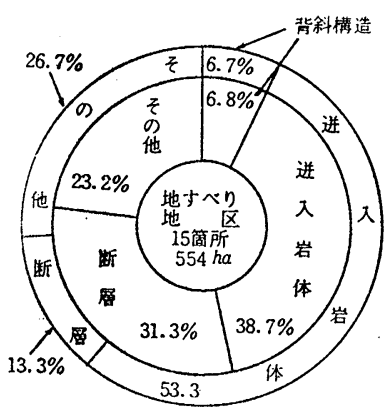

津川曆地すべり地における地算構 造区分

外側数字は箅所数の\% 内側数字は面槙の\%

(2)

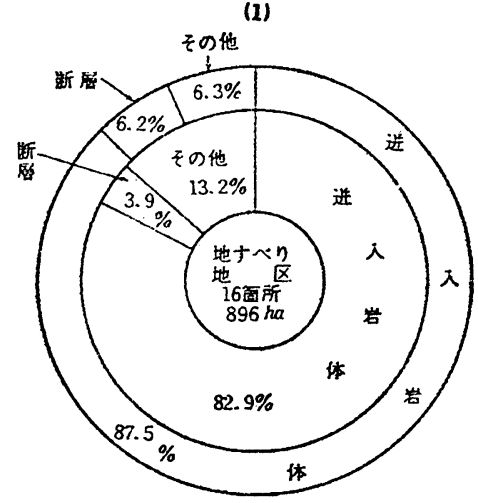

岩船層地すべり地における地質構 造区分

外側数字は箅所数の\%

内側数字は面櫝の \%
(2)

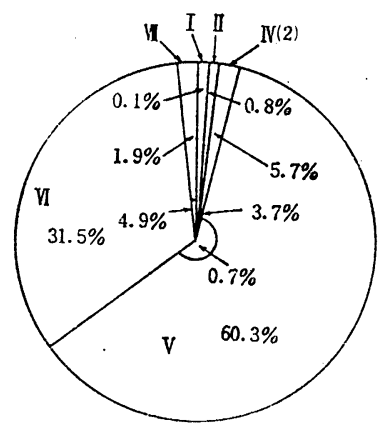

津川曆の地域別面槕比（外側の数 字）とその地筧における地すべり 面秛此
(3)

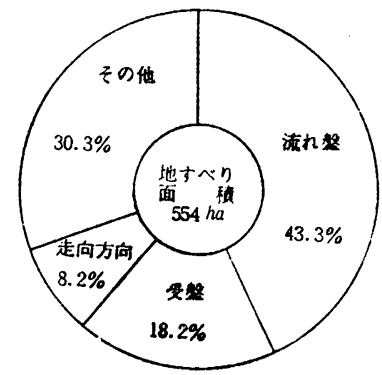

津川曾の地すべり方向と地歷の走 向, 傾斜の関係

図-6

(2)

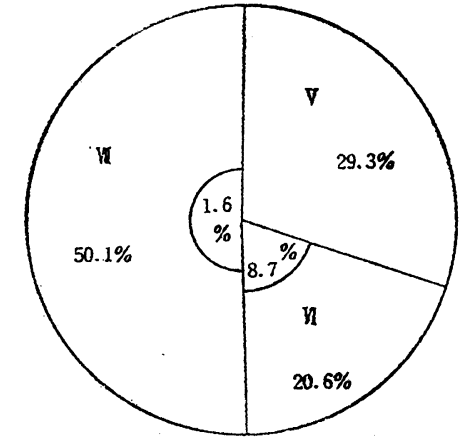

岩船層の地域別面積比とその地層 における地すべり面積比（内側数字）

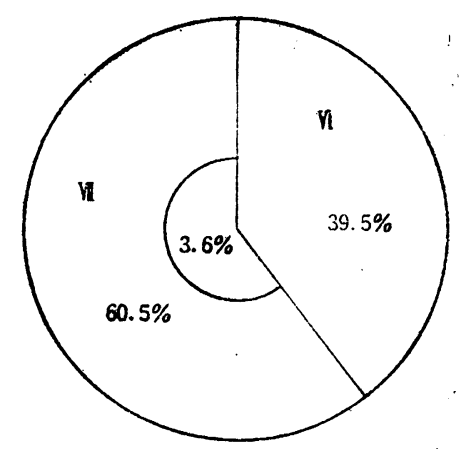

相川犀の地域別面稹比とその地居における 地すへり面積比（内側の数字）

图-7

图-8

すべりは $82.9 \%$ を占め圧倒的である。そして, 褶曲構 造の影響がほとんどないことが特徽的である。

このことはまた, 岩船層の地域別面積比と地すべり面 積比をあらわした同図(2)にもあらわれている。すなわ ち，岩船層の地すべりは火成岩の迸入が多くみられるVII 地域（佐渡）拉よび И地域（阿賀野川以北）に発生し, 他地域ではみられない。

岩船層の地すべり地では貫入や断層のため, 地層の破 砕が著しいため，これまで述べてきた地層のように地す ベり方向と地層傾斜の関係を分類することが困難であ り：また無意味でもあるのではぶいた。

（8）相川層

相川層は分布地域が限られ， ：佐渡およびり地域のみ で, しかも地すべり発生面積比も小さく, 地すべりと地
質構造との関係をとくに指摘するほどの資料にそしい が，強いてあげれば貫入体との関係が深い。

\section{8. 考察}

地すべり発生分布と地質および地質構造の関係につい ては，これまでいくつかの研究がなされてきた。しかし 地質的な地域分類と地層別分類を行うことなく解析した ため, 地すべりの発生と地質的要因の相関を追及し得な い部分が多かった。しかし 以上の解析によりこれまで 明らかでなかったり，相関がないと考えられていた部分 を解明することができた。

以上の点を総括的に考察すると，つぎの諸点が指摘さ れよら。

（1）新潟県の地すべりの発生分布は, ‘面積の上で 
III地域（関川〜鲭石川地域）に46.7\%， II 地域（姫川〜 関川地域）に23.2\%を占め，この 2 地域だけで実に 69.9 \%に達する。

両地域とも新第三紀層の分布が地域の大半を占めると 共に， III 地域では褶曲構造が， II 地域では断層と貫入岩 体の発達が著しく, このことが地すべり発生の有力な要 因となっている。そして両地域の地すべりは椎谷・寺泊 層, 西山層, 灰爪層および七谷層に発生し，この各層に 占める地すべり面積比が他地域よりきわめて高くなって いる。

(2) III， II 地域についで地すべりの発生の多いのはN 地域（中越・魚沼西側）であり, 地すべり面積の $20.2 \%$ を占めている。この地域の地すべりは, 前述の 2 地域の 各層中に占める地すべり面積比よりかなり低く，また， 第四紀層地すべりが多く, しかも魚沼層, 灰爪層および 西山層中の地すべり面積比がほぼ同じであるなどの特徵 を示している。これはこの地域の褶曲度が低いことを反 映したものと考えられる。

（3）新潟県の中・古生層地すべりは, 主として I 地域 (姫川以西) に分布し. 県下の地すべり面積の $3.4 \%$ と なっている。この地域は構造線による破砕がすすみ,こ れが地すべり発生の誘因となっている。

（4） V 地域 (中越 ·魚沼東側), V地域 (阿賀野川以 北）および四地域（佐渡）では地すべりの発生頻度は低 く, これら 3 地域をあわせても県下の地すべり面積の 6.5\% を占めるにすぎない。これらの地域の地すべりは 主として椎谷 · 寺泊層より古い地層に限られていること と貫入岩体や断層の影響をうけていることが特徽的であ る。

（5）魚沼層の地すべり（第四紀層地すべり）は，地層 の傾斜と地形傾斜が一致している場合に最も発生しやす い。魚沼層は, 砂磷, 砂, シルトなどが比較的厚い不規 則な互層を形成している。したがって, 透水性のよい砂 磷層の下盤に不透水性のシルトが存在する場合, 地下水 位が上昇すると, 間隙水王が増大し, 斜面土塊のセン断 強度が低下して地すべり齐発生する。魚沼層の地すべり は, この地層特有の成層状態と, それによる地下水の影 謷が支配的である。そのため流れ盤型の地すべり発生頻 度がたかくなるのである。このことは岩永の結果とも一 致して扣り,さらに岩永は魚沼畨の地すべりは地下水が 敏感に関与し，地層が剝離性をもっているため，大規模 な地すべりを発生すると指摘している。

(6) 灰爪凮の地すべりは, 固結度の低い細粒砂岩, シ ルト岩および砂岩などからなっているが，魚沼層よりは るかに透水性が低いため, 地層の傾斜に支配されて地す ベりが発生することはすくない。

死爪層は, 隆起量の関係で背斜軸の頂部を占めている ことがすくないため, 褶曲構造との関係は顕著ではな
い。しかし, 地域別の地すべり発生状況から見て, 断層 および褶曲構造の影響を間接的にうけていると見ること がでさる。

（7）西山層の地すべりは，地すべり占有面積比がいず れの地域でもほぼ同様の值をなし，また地質構造の影響 も顕著でない点は灰爪層と似ている。

（8）背斜軸の近くに地すべりが集中的に発生すること は, 津田, 岩永, 岩松等が指摘しているところである が, 椎谷・寺泊層の地すべりではこれが最も顕著であ る。このことは褶曲度の高い地域でこの地層の分布が顕 著であって, しかも, 背斜軸周辺を椎谷・寺泊層が占 有し，地形的背梁部をなしていることが地すべり発生の 有力な原因となっている。

それと共に，椎谷・寺泊層は黒色泥岩を主体とし，砂 岩および凝灰岩を挾在する。これらの岩質は地下゙ではむ しろ堅硬であるが, 露出すると風化しやすく, 岩塊状に 風化することは稀で, 直接粘土化する特性を持ってい る。そして，泥岩から風化によりできた地すべり地の土 の乱さない試料のせん断強さと乱した試料のセン断強さ の差がきわめて小さく，ときには乱した粘土のせん断強 度が乱さない粘土のそれより大さいことがしばしばある (鋭敏比が 1.以下)。したがって，一次的地すべりが発 生すると, 慢性的に移動を反復するような黒色泥岩に特 有の物性と力学的性質をもっている。

（9）七谷層は硬質頁岩が主体で. 椎谷 · 寺泊層の黑色 泥岩よりさらに固結度が高いため, 褶曲度よりはむしろ 断層や貫入岩体の影響による地すべりが発生する傾向を 示す。この傾向は津川層, 岩船層へ時代が古くなるにし たがってより顕著となる。

(10) 相川層の地すべりはほとんどが貫入岩体の影㗽を らけて発生している。相川層は七谷・津川層よりさらに 地層は堅硬であるにもかかわらず，地すべりが発生する のは相川層における貫入による破砕作用は著しく, 構造 線に拈ける破砕に匹敵することも多いからである。従来 から，構造線にそった地域の地すべりを破砕帯地すべり と呼び, この地域は中・古生層地带に多いため, 破䂶带 地すべり, 即中・古生層地すべりと考えられがちである が，第三紀層であっても断層や火成岩の貫入により破砕 され，地すべりが発生していることに注目しなければな らない。そして，微視的には褶曲構造による地すべりは 軽度の破砕の影響をらけた地すべりと見ることができ る。

(11) I 地域（姬川以西）に破砕帯地すべりが集中的に 発生している。新潟県ではとくに系魚川一静岡線にそっ て帯状に地すべり地が配列しているのが特徴的で, 中生 代の来馬層, 蛇紋岩, 古生代の粘板岩拉よび結晶片岩に 地すべりが発生している。

このほか岩船郡执よび佐渡にも少数ではあるが, 古生 
層に地すべりが発生している。これらは姫川流域の構造 線による破砕帯地すべりとは異なり，貫入岩体の影響に よるものである。

また, 貫入岩体の周辺には断層が存在することが多 く, 中・古生層のように堅硬な岩石でも, それらの影響 により, 破砕され, 地すべりが発生する可能性が強くな っている。

\section{9. 結 言}

新潟県の地すべりと地質との関係についてはいくつか の研究成果がある。この解析は新潟県地質図の改訂版が 出版されたのを機に，正確な地すべり防止区域の統計資 料にもとついて, 地域的な解析も含め全県的考察を行っ た。

この解析にあたり御指導頂いた津田禾粒教授（新潟大 学)に深く感謝いたします。

\section{参考文献}

1）岩松暉，服部昌樹，西田彰一(1967)：第三紀層地すべりと 岩質および地質構造との関係 一新潟県下の第三紀層地すべ りについてー 災害地質討論会論文集

2) 岇松喗 (1975)：新潟県下の地すべりとしゅら曲作用 新潟 大学理学部地盤災害研究施設研究年報第 1 号

3）岩永伸, 永田聡, 津田禾粒. 山野井徹 (1972)：芦川地すへ り一古期地すべりの地史学的考察の一例- 地すべり Vol. 14, No. 1

4）岩永伸 (1974)：新潟県下に分布する魚沼層群の地すべりと 地質構造との関係について(1) 地すべりVol. 11, No.4

5）岩永伸(1976)：灰爪層地すべりの概要 一とくにその解析結 果について一新潟大学理学部地質鉱物学教室研究報告第 4 号

6）津田禾粒，岩永伸，西田彰一（1967)：第三紀層地すべりと 岩質および地質構造との関係一新潟県下の第三紀層地すべり について一 災害地質討論会論文集

7) 津田禾粒, 岩永伸, 永田聡(1970): 地すへり多発時代の提 言 地すべり第 9 回研究発表会

(原稿受理日 昭和55年11月 1 日）

\section{正潩 表}

第17巻, 第 3 号（通巻第63号）

新潟県の地すべりと地質および地質構造の関係（1）

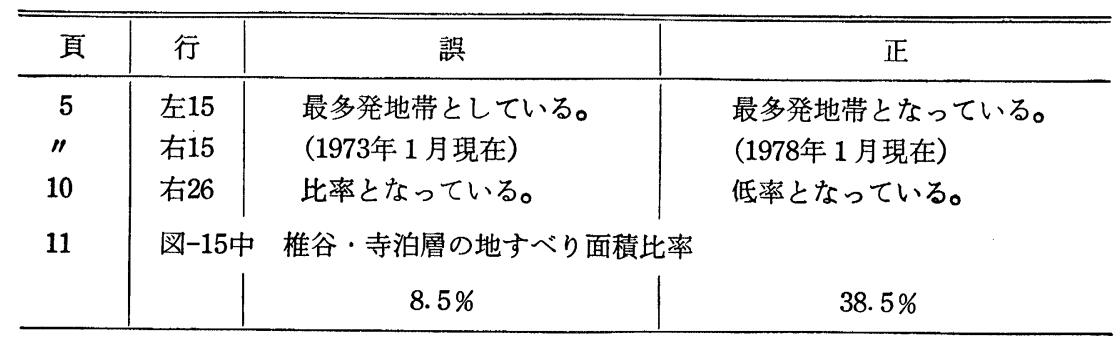

